\title{
Effects of lactic acid-producing bacteria as direct-fed microbials on the ruminal microbiome
}

\author{
H. F. Monteiro, ${ }^{1,2}$ A. L. J. Lelis, ${ }^{2,3}$ P. Fan, ${ }^{2}$ B. Calvo Agustinho, ${ }^{2}$ R. R. Lobo, ${ }^{2}$ J. A. Arce-Cordero, ${ }^{2}$ X. Dai, ${ }^{2,5}$ \\ K. C. Jeong, ${ }^{2}$ and A. P. Faciola ${ }^{2 *}$ \\ ${ }^{1}$ Department of Population Health and Reproduction, School of Veterinary Medicine, University of California, Davis 95616 \\ ${ }^{2}$ Department of Animal Sciences, University of Florida, Gainesville 32611 \\ ${ }^{3}$ Faculdade de Medicina Veterinária e Zootecnia, Universidade Estadual Paulista Júlio de Mesquita Filho, Botucatu, Brazil, \\ 18618-681 ${ }^{4}$ Department of Animal, Veterinary, and Food Sciences, University of Idaho, Moscow 83844 \\ ${ }^{5}$ Department of Clinical Science Services, Royal Veterinary College, London, UK, NW1 OTU
}

\begin{abstract}
The objective of this study was to evaluate ruminal microbiome changes associated with feeding Lactobacillus plantarum GB-LP1 as direct-fed microbials (DFM) in high-producing dairy cow diets. A dual-flow continuous culture system was used in a replicated $4 \times 4$ Latin square design. A basal diet was formulated to meet the requirements of a cow producing $45 \mathrm{~kg}$ of milk per day (16\% crude protein and $28 \%$ starch). There were 4 experimental treatments: the basal diet without any DFM (CTRL); a mixture of Lactobacillus acidophilus, $1 \times 10^{9} \mathrm{cfu} / \mathrm{g}$, and Propionibacterium freudenreichii, 2 $\times 10^{9} \mathrm{cfu} / \mathrm{g}[\mathrm{MLP}=0.01 \%$ of diet dry matter $(\mathrm{DM})]$; and 2 different levels of $L$. plantarum, $1.35 \times 10^{9} \mathrm{cfu} / \mathrm{g}$ $(\mathrm{L} 1=0.05 \%$ and $\mathrm{L} 2=0.10 \%$ of diet DM). Bacterial samples were collected from the fluid and particulate effluents before feeding and at 2, 4, 6, and $8 \mathrm{~h}$ after feeding; a composite of all time points was made for each fermentor within their respective fractionations. Bacterial community composition was analyzed through sequencing the V4 region of the $16 \mathrm{~S}$ rRNA gene using the Illumina MiSeq platform. Sequenced data were analyzed on DADA2, and statistical analyses were performed in R (RStudio 3.0.1, https://www.r-project $. \mathrm{org} /$ ) and SAS 9.4 (SAS Institute Inc.); orthogonal contrasts were used to compare treatments. Different than in other fermentation scenarios (e.g., silage or beef cattle high-grain diets), treatments did not affect $\mathrm{pH}$ or lactic acid concentration. Effects were mainly from overall DFM inclusion, and they were mostly observed in the fluid phase. The relative abundance of the phylum Firmicutes, family Lachnospiraceae, and 6 genera decreased with DFM inclusion, with emphasis on $\mathrm{Bu}$ tyrivibrio_2, Saccharofermentans, and Ruminococcus_1
\end{abstract}

Received July 16, 2021.

Accepted November 3, 2021.

*Corresponding author: afaciola@ufl.edu that are fibrolytic and may display peptidase activity during fermentation. Lachnospiraceae_AC2044_group and Lachnospiraceae_XPB1014_group also decreased in the fluid phase, and their relative abundances were positively correlated with $\mathrm{NH}_{3}-\mathrm{N}$ daily outflow from the fermentors. Specific effects of MLP and L. plantarum were mostly in specific bacteria associated with proteolytic and fibrolytic functions in the rumen. These findings help to explain why, in the previous results from this study, DFM inclusion decreased $\mathrm{NH}_{3}-\mathrm{N}$ concentration without altering $\mathrm{pH}$ and lactic acid concentration. Key words: Butyrivibrio, Lactobacillus plantarum, Lactobacillus acidophilus, Propionibacterium freudenreichii

\section{INTRODUCTION}

Lactic acid bacteria (LAB) have long been used as silage inoculants, as they establish well in various forages and rapidly reduce silage $\mathrm{pH}$ through lactic acid production (Kung et al., 2003; Muck et al., 2018). In addition to improving silage fermentation, some LAB such as Lactobacillus plantarum are aerotolerant (Pedersen et al., 2012) and may survive in the silage until it is fed to animals. Cows consuming silage inoculated with these LAB improve lactation performance, even when these effects do not fully come from silage fermentation (Kung et al., 2003; Oliveira et al., 2017; Monteiro et al., 2021). The possible reason for this is that these bacteria further ferment substrates in the rumen, altering the ruminal microbiome and their fermentation end products (Weinberg et al., 2003, 2004a,b). Although the literature is robust regarding the mode of action of LAB in silage, little is known about their mechanism in the rumen (Muck, 2013; Oliveira et al., 2017; Monteiro et al., 2021).

A major concern related to feeding LAB directly to dairy cows is to further decrease ruminal $\mathrm{pH}$ through a greater lactic acid accumulation, which may increase 
chances of SARA (Plaizier et al., 2008). Thus, in vivo studies investigating LAB as direct-fed microbials (DFM) commonly feed them in combination with lactic acid-utilizing bacteria (Raeth-Knight et al., 2007; Boyd et al., 2011; Philippeau et al., 2017). The latter ferment lactic acid into propionic acid, which increases propionic acid supply to the animal and reduces the accumulation of ruminal lactic acid (McAllister et al., 2011), which reduces the risk of SARA due to LAB as DFM in the diet (Raeth-Knight et al., 2007; Philippeau et al., 2017).

Little has been studied, however, about other mechanisms by which these LAB could affect the rumen microbiome. In lactation performance studies, LAB from silage inoculants likely improve ruminal $\mathrm{N}$ metabolism in dairy cows as well (Kung et al., 2003; Muck, 2013; Oliveira et al., 2017). Contreras-Govea et al. (2011, 2013) showed that LAB-inoculated silage yielded greater microbial biomass and microbial NAN than untreated silage during ruminal fermentation in vitro. Although some of these LAB effects may be because of changes in silage fermentation, an effect on ruminal $\mathrm{N}$ metabolism is of great importance to high-producing dairy cows. Thus, such outcomes from feeding LAB as DFM to dairy cows should be considered.

Aiming at elucidating the mode of action of LAB as DFM in the rumen, our companion study (Monteiro et al., 2020) evaluated the DFM effects of LAB at 2 inclusion rates (L. plantarum GB-LP1; L1 and L2) as well as of known lactic acid-producing and -utilizing bacteria (Lactobacillus acidophilus NP51 and Propionibacterium freudenreichii NP24; MLP) in high-producing dairy cow diets $(16 \% \mathrm{CP}$ and $28 \%$

Table 1. Ingredients and chemical composition (\% of DM unless otherwise stated) of the basal diet used in the study

\begin{tabular}{lc}
\hline Item & Basal diet \\
\hline Ingredient & \\
Alfalfa hay & 14.0 \\
Corn silage & 46.0 \\
Ground corn & 23.3 \\
Solvent soybean meal 48\% CP & 14.2 \\
Vitamin and mineral premix & 2.50 \\
Chemical composition & \\
OM & 93.7 \\
CP & 16.0 \\
RDP & \\
RUP & 1 \\
NDF & 9.57 \\
Forage NDF $_{\text {NFC }}^{2}$ & 6.40 \\
Starch & 31.7 \\
Ether extract $_{\text {NE }}{ }^{2}$ Mcal/kg of DM & 28.3 \\
\end{tabular}

${ }^{1}$ Estimated using the NRC (2001) model.

${ }^{2} \mathrm{NFC}=100-(\% \mathrm{NDF}+\% \mathrm{CP}+\%$ fat $+\%$ ash $)$, according to NRC (2001). starch). Supplementation with LAB and MLP reduced ruminal $\mathrm{NH}_{3}-\mathrm{N}$ concentration in vitro compared with those without DFM supplementation, suggesting possible effects on microbial $\mathrm{N}$ metabolism. Based on these findings, we hypothesized that MLP, L1, and L2 would all decrease ruminal bacteria associated with AA deamination during fermentation. Therefore, the objective of the current study was to evaluate the ruminal microbiome changes when MLP, L1, and L2 were fed as DFM to high-producing dairy cow diets in a dual-flow continuous culture system. The second objective was to evaluate whether the tested DFM affect microbial $\mathrm{N}$ metabolism by modifying different microbial communities, and whether different inclusion rates of $L$. plantarum GB-LP1 (L1 vs. L2) could have further effects on these populations.

\section{MATERIALS AND METHODS}

\section{Ethical Approval}

Care and handling of all ruminally cannulated animals used in this study were conducted under protocols approved by the Institutional Animal Care and Use Committee of the University of Florida (Gainesville).

\section{Experimental Design, Treatments, and Sampling}

A basal diet was formulated following the NRC (2001) recommendations for a lactating Holstein cow of $680 \mathrm{~kg} \mathrm{BW}, 90$ DIM, $27 \mathrm{~kg}$ of DMI per day, and producing $45 \mathrm{~kg}$ of milk per day. Diets were formulated to have a 60:40 forage-to-concentrate ratio and to contain $16 \% \mathrm{CP}$ and $30 \%$ of starch (DM basis; Table 1). All dietary ingredients used for the entire experiment were from the same batch of feed, and they were ground on the same day. The corn silage was pre-dried at $60^{\circ} \mathrm{C}$ for $48 \mathrm{~h}$ to allow partial dryness ( $>90 \% \mathrm{DM})$ of the material before grinding. Dietary ingredients were ground to pass a 2-mm sieve using a Wiley mill (Arthur H. Thomas Co.). Then, each ingredient was individually homogenized, and a subsample $(500 \mathrm{~g})$ from each of the ingredients was ground to pass a 1-mm sieve for chemical analysis. All ground materials were properly stored in a $21^{\circ} \mathrm{C}$ and $50 \%$ humidity-controlled environment for later use.

The experimental treatments were chosen based on preliminary studies evaluating the effects of L. plantarum as DFM on in vitro ruminal fermentation, nutrient digestibility, and N utilization (Monteiro et al., 2020). A total of 4 treatments were used in this study, and all treatments were composed of the basal diet with the addition of one DFM, excluding the control, which had no DFM. All DFM used in the study were in the solid 
form $(<1$-mm particle size) and were added to the basal diet in a partial replacement of ground corn. Therefore, treatments were a negative control $(\mathbf{C T R L}=$ basal diet without additives); a mix of lactic acid-producing and -utilizing bacteria (MLP $=0.01 \%$ of diet DM of mixed L. acidophilus NP51, $1 \times 10^{9} \mathrm{cfu} / \mathrm{g}$, and P. freudenreichii NP24, $2 \times 10^{9} \mathrm{cfu} / \mathrm{g}$ ) as a positive control; and 2 inclusion levels of the LAB L. plantarum GB-LP1, 1.35 $\times 10^{9} \mathrm{cfu} / \mathrm{g}(\mathrm{L} 1=0.05 \%$ and $\mathrm{L} 2=0.10 \%$ of $\operatorname{diet} \mathrm{DM})$. The MLP used in this study is a known MLP obtained from a commercial setting. Different strains of lactic acid-producing bacteria were used in MLP and L1 and L2 treatments to test whether a lactic acid-producing bacterium, independent of the strain, could alone have similar effects as a known MLP.

Eight dual-flow continuous culture fermentors $(1,820$ $\mathrm{mL}$ each) originally developed by Hoover et al. (1976) and modified by Del Bianco Benedeti et al. (2015), Silva et al. (2016), Paula et al. (2017), and Brandao et al. (2018) were used in a replicated $4 \times 4$ Latin square design. There were 4 experimental periods, each consisting of $11 \mathrm{~d}$ of in vitro fermentation. Experimental treatments were randomly assigned to a fermentor within square at the beginning of each experimental period. The first $7 \mathrm{~d}$ of fermentation were used for diet adaptation, and the following $4 \mathrm{~d}$ were used for sample collections. All procedures performed during the adaptation period were previously described in Monteiro et al. (2020). On d 7 (1 d before sampling) and through the rest of the period, the effluent containers were immersed in a chilled water bath $\left(<2^{\circ} \mathrm{C}\right)$ to stop microbial activity. On d 8, 9, and 10, samples of $15 \mathrm{~mL}$ from the filtered effluent containers were collected in $50-\mathrm{mL}$ centrifuge tubes before feeding and at 2, 4, 6, and $8 \mathrm{~h}$ after the morning feeding for analysis of bacteria community composition (BCC) of the fluid phase. Samples were composited per time point across the 3 collection days, totaling $45 \mathrm{~mL}$ collected from each fermentor per time point per period. Simultaneously, $200 \mathrm{~mL}$ of the effluent was collected, and the solids were retained after being strained through 4 layers of cheesecloth for BCC analysis of the particulate phase. Approximately $25 \mathrm{~g}$ of solids were then collected at each time point and composited in the same manner as the liquid samples. All samples were stored at $-80^{\circ} \mathrm{C}$ for further bacterial isolation and DNA extraction and sequencing analysis.

On d 9, 10, and 11, a 500-g sample was taken from the mixed fluid and particulate effluents of each fermentor and stored at $-20^{\circ} \mathrm{C}$ for further analysis of DM, ash, and CP. At the end of d 11, the entire fermentation contents from each fermentor were used for bacterial isolation to calculate the $\mathrm{N}$ fractions during fermentation. All chemical analyses and calculations for $\mathrm{N}$ me- tabolism variables were previously described in Paula et al. (2017) and Monteiro et al. (2020). In brief, total $\mathrm{N}$ remaining after the fermentation was partitioned in $\mathrm{NH}_{3}-\mathrm{N}$ and NAN (undegraded feed $\mathrm{N}$ and bacterial $\mathrm{N}$ ). Outflow of each of these fractions from fermentation were calculated following the equations described by Calsamiglia et al. (1996) and Bach and Stern (1999), with the former also used to calculate dietary $\mathrm{N}$ flow, bacterial efficiency, and efficiency of $\mathrm{N}$ utilization.

\section{DNA Extraction}

Bacterial DNA was extracted from the composite samples of the fluid and particulate phases following the procedure from Stevenson and Weimer (2007). This procedure follows a phenol-chloroform extraction method with bead beating and has previously been described by Dai et al. (2017) for samples collected from dual-flow continuous culture fermentors. Briefly, samples were thawed at room temperature on the day of DNA extraction, and $24 \mathrm{~mL}$ of the samples from the fluid phase as well as $24 \mathrm{~g}$ of the solids from the particulate phase were used in the procedure. Solids from the particulate phase were blended with a DNA extraction buffer composed of Tris $\mathrm{HCl}$, EDTA, and $\mathrm{NaCl}$, to detach bacteria from feed particles. The blended content was subsequently centrifuged at a low speed $\left(500 \times g\right.$ for $15 \mathrm{~min}$ at $\left.4^{\circ} \mathrm{C}\right)$ to remove feed particles. The supernatant was collected and centrifuged again at high speed $\left(10,000 \times g\right.$ for $25 \mathrm{~min}$ at $\left.4^{\circ} \mathrm{C}\right)$ to isolate the bacterial pellet. The pellet was then collected and resuspended in DNA extraction buffer. The liquid samples from the fluid phase were directly centrifuged at high speed again, and the same steps for collecting the pellet of bacteria and resuspending them in DNA extraction buffer were performed.

The bacterial cells were then mechanically and chemically disrupted by SDS and repeated events of bead beating, cooling down, and heating $\left(60^{\circ} \mathrm{C}\right)$. Briefly, resuspended bacterial cells were added into a $2-\mathrm{mL}$ DNase-free screw-cap microcentrifuge tube containing zirconium beads (BioSpec Products), 20\% sodium lauryl sulfate solution, and phenol; physical disruption of the cells was performed using a bead beater machine (Biospec Products). The microcentrifuge tube was centrifuged, and the DNA collected by a series of extractions with phenol, phenol/chloroform, and chloroform. The pellet of DNA was obtained by a precipitation in 3 $M \mathrm{Na}$ acetate buffer and isopropanol. Then, the DNA pellets were centrifuged twice with a $70 \%$ ethanol solution, and after evaporation the pellet was resuspended in Tris-EDTA buffer. Before storage in $-80^{\circ} \mathrm{C}$, the DNA concentration was measured using a Qubit Fluorometer 
(Invitrogen), and DNA from different hours but from the same fermentor was pooled in equal proportions to yield 1 sample for each fermentor per period.

\section{DNA Sequencing}

Procedures for DNA sequencing were performed according to Kozich et al. (2013). Briefly, amplification was performed with PCR in a C1000 Touch Thermal Cycler (Bio-Rad). The V4 region of the 16S rRNA gene was amplified by dual-index universal bacterial primers (forward: GTGCCAGCMGCCGCGGTAA; reverse: GGACTACHVGGGTWTCTAAT) through an initial denaturation of $5 \mathrm{~min}$ under $95^{\circ} \mathrm{C}$, followed by 30 cycles of $30 \mathrm{~s}$ at $95^{\circ} \mathrm{C}, 30 \mathrm{~s}$ at $55^{\circ} \mathrm{C}, 1 \mathrm{~min}$ at $72^{\circ} \mathrm{C}$, and $5 \mathrm{~min}$ for final elongation at $72^{\circ} \mathrm{C}$. Forward and reverse primers, as well as small DNA fragment contaminants, were removed using a 1\% low-melting agarose gel extraction kit (National Diagnostics). Amplicons were then purified and normalized using a SequalPrep plate kit (Invitrogen), and the DNA concentration was measured with a Qubit fluorometer. Adapters were added to the amplicons, and the DNA library was constructed by equally pooling all the amplicons together and using quantitative real-time PCR for quality check. A total of 32 samples from the fluid phase and 32 from the particulate phase were sequenced. Sequencing was performed using a MiSeq reagent kit V2 $(2 \times 250$ cycles run; Illumina) in an Illumina MiSeq platform at the Interdisciplinary Center for Biotechnology Research of the University of Florida (Gainesville). All sequences were deposited in the Sequence Read Archive of the National Center for Biotechnology Information (https: //www.ncbi.nlm.nih.gov/sra) under access no. PRJNA772193.

\section{Taxonomic Analyses}

Sequenced amplicons were processed using the DADA2 pipeline package in $\mathrm{R}$ (Callahan et al., 2016), similarly to de Assis Lage et al. (2020); taxonomy assignment was performed using the $16 \mathrm{~S}$ rRNA SILVA v. 132 database (Pruesse et al., 2007). The DADA2 pipeline is an improvement from the Divisive Amplicon Denoising Algorithm (DADA) from Rosen et al. (2012), which allows a higher-resolution inference to the sequenced amplicons compared with traditional denoising algorithms that are based on similarity clustering. In DADA2, inference was based on a single-nucleotide difference (amplicon sequence variants) instead of similarity proportions used by operational taxonomy units. Therefore, taxonomy assignment in this study was based on amplicon sequence variants and not op- erational taxonomy units, to improve the accuracy of our BCC analysis.

Briefly, paired-end fastq files were demultiplexed, and the quality profiles of the forward and reverse readings were separately inspected, filtered, and trimmed based on the relationship between error rates and quality scores. Forward and reverse readings were then merged, chimeras were removed, and an amplicon sequence variants table was created. Taxonomy was assigned using the SILVA database described earlier, and a phyloseq object was created using the phyloseq package in R (McMurdie and Holmes, 2013). The relative abundances were calculated also using the phyloseq package in $\mathrm{R}$, and the data was split into the different taxonomic levels for statistical analyses. Heatmaps and bar graphs were generated using the ggplot2 package in R (Wickham, 2016).

Shannon and Chao 1 indexes were obtained through the microbiome (Lahti and Shetty, 2017) and vegan (Oksanen et al., 2020) packages in R. To visualize possible differences in BCC composition, a second denoising algorithm called Prevalence Interval for Microbiome Evaluation (PIME) was applied to the paired-end readings (pime package in R; Roesch et al., 2020). This algorithm allows for the separation of noise across samples from biologically significant findings. In PIME, taxa were filtered through random forest classifications and noise removed through prevalence intervals, from which taxa that were not shared, given an ideal prevalence interval within an independent group [fractionation (bacteria in the fluid vs. particulate phases) and experimental treatments], were removed for better visualization of community differences.

\section{Statistical Analyses}

Statistical analyses were carried out in R (RStudio 3.0.1, https://www.r-project.org/) and SAS 9.4 (SAS Institute Inc.). In R, principal component analysis plots were generated using the pime package (Roesch et al., 2020) for the purpose described earlier. The bacterial community composition (Jaccard) and structure (Bray-Curtis) between the fluid and particulate phases (fractionation), treatments in the whole $\mathrm{BCC}$, and treatments within fluid and particulate phases, were analyzed using the pairwise.adonis analysis from the vegan package (Callahan et al., 2016). Correlation analysis was performed between the ruminal $\mathrm{N}$ metabolism variables [daily flow (g) unless otherwise stated: $\mathrm{NH}_{3}-\mathrm{N}$, RDP-N, RUP-N, bacterial N, efficiency of N utilization $(\%)$, and bacterial efficiency (\%)] and between bacterial taxa that differed between treatments using the Pearson correlation procedure. The significance threshold 
was declared at $P \leq 0.05$ and tendencies at $0.05<P$ $\leq 0.10$.

In SAS, relative abundances from the fluid and particulate phases, as well as ruminal $\mathrm{N}$ metabolism data, were analyzed using the GLIMMIX procedure in a replicated $4 \times 4$ Latin square design. The model used was as follows:

$$
\mathrm{Y}_{i j k l}=\mu+\mathrm{S}_{i}+\mathrm{P}_{j}+\mathrm{F}(\mathrm{S})_{k i}+\mathrm{T}_{l}+\mathrm{E}_{i j k l},
$$

where $\mathrm{Y}_{i j k l}$ is the response variable, $\mu$ is overall mean, $\mathrm{S}_{i}$ is the effect of Latin square $(i=1$ or 2$), \mathrm{P}_{j}$ is the random effect of period $(j=1$ to 4$), \mathrm{F}(\mathrm{S})_{k i}$ is the random effect of fermentor $(\mathrm{F})$ within square $(k=1$ to $4), \mathrm{T}_{l}$ is the effect of treatment $(l=1$ to 4$)$, and $\mathrm{E}_{i j k l}$ is the residual error. Orthogonal contrasts were used to compare CTRL vs. DFM; MLP vs. L1 and L2; and L1 vs. L2. Significance was also declared at $P \leq 0.05$ and tendencies at $0.05<P \leq 0.10$.

\section{RESULTS AND DISCUSSION}

A total of 2,909,515 sequences were yielded at the end of the $16 \mathrm{~S}$ rRNA sequencing and DADA2 pipeline, from which sequencing, filtering, denoising, merging, and the removal of chimeras were applied. These sequences were generated from the 32 samples of the fluid phase and 32 samples from the particulate phase that DNA was extracted. Based on those sequences, a total of 11,027 taxa were identified after taxonomy assignment. Because the DNA was extracted considering the fractionation of bacterial communities (fluid and particulate phases), results are presented within their respective fractionations.

The profile of bacterial communities is reported in Figure 1. Principal component analysis through PIME shows differences in the core microbiome of the fluid and particulate phases of fermentation. In fact, we observed differences in the bacterial community structure (Bray-Curtis) and composition (Jaccard) for fractionation in our study (Figure 1). These results confirmed the differences we expected for both bacterial groups in the fluid and particulate phases (Czerkawski, 1986; Henderson et al., 2013). These groups were previously described by Czerkawski (1986) as being composed of bacteria in the free-floating state mixed with others loosely attached to particles (fluid phase), and of bacteria firmly attached to particles (particulate phase).

Regarding the treatments, we could not detect major differences among their community composition (Figure 1). However, we observed an effect of L. plantarum inclusion level on Chao 1 Shannon indexes of the bacterial community in the fluid phase, in which
L1 decreased both parameters (Table 2). The decrease in richness and diversity for L1 compared with L2 treatments represents a possible negative effect of the lower inclusion level of $L$. plantarum on some specific bacterial groups as well as on the overall abundance of the microbial populations (Whittaker, 1972). These results suggest a greater effect of L1 compared with L2 on the microbial population. The principal component analysis plots also show a small distinction between treatments, which could be associated with the findings from our companion study (Monteiro et al., 2020), which reported improvements in $\mathrm{N}$ metabolism for the DFM treatments. Therefore, to identify smaller differences between treatments, we evaluated the relative abundances of individual bacteria taxa from fermentation throughout the different taxonomic levels and report them herein.

\section{Effects on Bacterial Community Phyla and Families}

A total of 18 phyla were identified in both the fluid and particulate phases; all phyla with a relative abundance greater than $0.50 \%$ are shown in Table 3 . The main phyla in both fractions were Bacteroidetes (fluid $=45.9 \%$; particulate $=39.5 \%$ ), Firmicutes (fluid $=29.9 \%$; particulate $=39.4 \%$, and Proteobacteria (fluid $=12.6 \%$; particulate $=9.06 \%$ ), in accordance with those reported by Henderson et al. (2015) in a study evaluating the rumen core microbiome across 32 ruminant species. The major difference between fractions was the increase in the relative abundance of Firmicutes in the particulate phase at the expense of a small decrease in Bacteroidetes and Proteobacteria. Regarding the less-abundant phyla among those with relative abundance greater than $0.50 \%$, Cyanobacteria and Tenericutes were more abundant in the fluid phase, whereas Fibrobacteres and Actinobacteria were more abundant in the particulate phases.

In the fluid phase, we observed a difference in the relative abundance of Firmicutes when DFM was included in the diet, with their relative abundance reduced compared with the control treatment. The decrease in Firmicutes was likely associated with a decrease in the relative abundance of its family, Lachnospiraceae, as reported in Table 4. Lachnospiraceae was the second most abundant family (12.4\%) after Prevotellaceae (36.2\%) in the fluid phase. The family Lachnospiraceae is composed of strictly anaerobic bacteria, which degrade a variety of carbohydrates in the rumen, such as pectin (Dehority, 1969), cellulose (Bryant and Small, 1956), and starch (Stackebrandt, 2014), but it also contains proteolytic (Wallace and Brammall, 1985; Wallace, 1996) and urealytic bacteria (Cook et al., 2007). Our 
Table 2. Effects of direct-fed microbials (DFM) on the bacterial $\alpha$ diversity of fermentors in a dual-flow continuous culture system

\begin{tabular}{|c|c|c|c|c|c|c|c|c|}
\hline \multirow[b]{2}{*}{ Item, \% } & \multicolumn{4}{|c|}{ Treatment $^{1}$} & \multirow[b]{2}{*}{ SEM } & \multicolumn{3}{|c|}{$P$-value ${ }^{2}$} \\
\hline & CTRL & MLP & L1 & L2 & & $\begin{array}{l}\text { CTRL vs. } \\
\text { additives }\end{array}$ & $\begin{array}{l}\text { MLP vs. } \\
\text { L1 and L2 }\end{array}$ & L1 vs. L2 \\
\hline Chao 1 & 689 & 703 & 653 & 777 & 39.8 & 0.62 & 0.79 & 0.03 \\
\hline Shannon & 6.27 & 6.25 & 6.15 & 6.33 & 0.06 & 0.77 & 0.94 & 0.05 \\
\hline \multicolumn{9}{|c|}{ Particulate phase } \\
\hline
\end{tabular}

${ }^{1}$ Additives in the basal diet for each treatment (\% of diet DM): CTRL = control (no DFM added); MLP = 0.01\% of a mix of Lactobacillus acidophilus and Propionibacterium freudenreichii; $\mathrm{L} 1=0.05 \%$ Lactobacillus plantarum; $\mathrm{L} 2=0.10 \%$ L. plantarum.

${ }^{2}$ Significant differences were considered at $P \leq 0.05$, and a tendency between $P>0.05$ and $\leq 0.10$.

companion study (Monteiro et al., 2020) reported no major changes in ruminal nutrient digestibility and short-chain fatty acid (SCFA) concentration but a decrease in ruminal $\mathrm{NH}_{3}-\mathrm{N}$ concentration when DFM was included in the diet. Therefore, the decrease in some Lachnospiraceae genera may be associated with AA deamination, stated earlier as the hypothesis of our study.
Another difference we observed in the fluid phase was the effect of $L$. plantarum on the relative abundance of Tenericutes, which was negatively affected by the L1 treatment. Tenericutes comprises a mixture of facultative and obligate anaerobes that lack a peptidoglycan cell wall, which makes this phylum possibly resistant to antibacterial molecules in the rumen (Krieg et al.,
A.
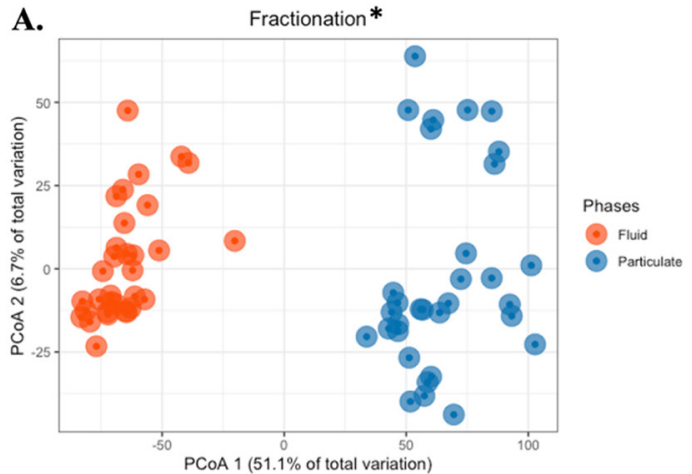

C.

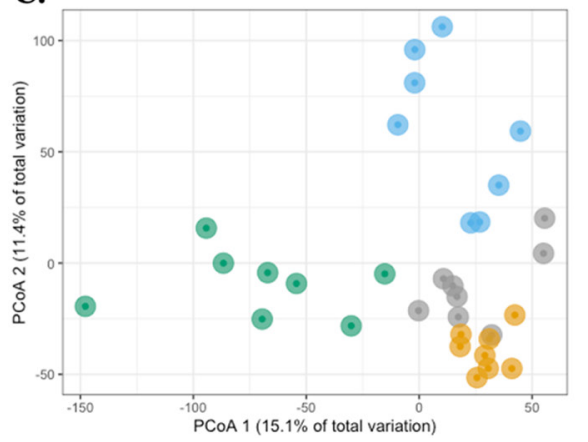

B.

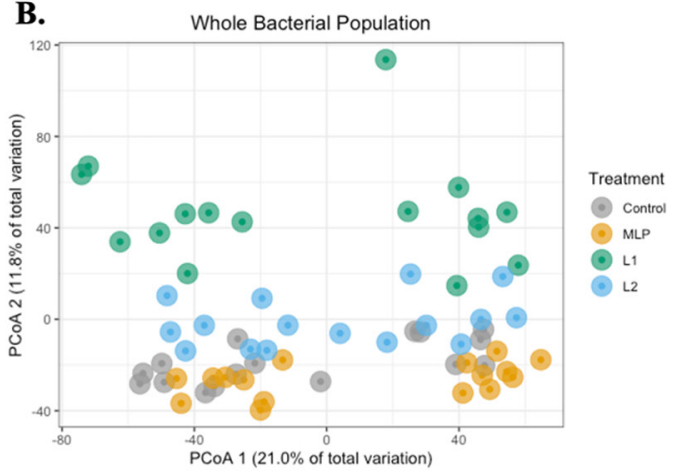

D.

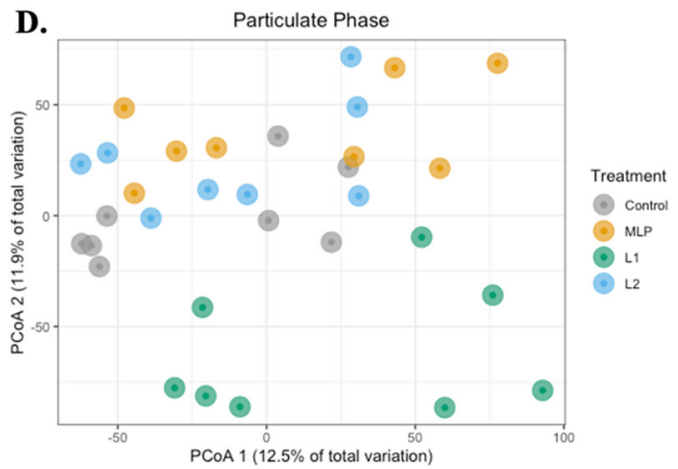

Figure 1. Profile of whole bacterial community between the fluid and particulate fractions of the ruminal contents (A) and among different experimental treatments (B). Panels C and D show the profiles of the bacterial communities among treatments in the fluid and particulate phases of the ruminal content. Principal coordinate analysis ( $\mathrm{PCoA}$ ) were constructed using Prevalence Interval for Microbiome Evaluation (PIME; pime package in R; Roesch et al., 2020) with the lowest out-of-bag error rate and prevalence interval of $35 \%$. * indicates differences $(P$ $<0.05)$ in bacterial community structure (Bray-Curtis) and composition (Jaccard); no trends were observed in profiling. Additive inclusion in the basal diet for each treatment: CTRL $=$ control (no additives); MLP $=0.01 \%$ of a mix of Lactobacillus acidophilus and Propionibacterium freudenreichii $\mathrm{L} 1=0.05 \%$ Lactobacillus plantarum; $\mathrm{L} 2=0.10 \%$ L. plantarum. 
Table 3. Effects of direct-fed microbials (DFM) on the relative abundance of bacterial phylum in a dual-flow continuous culture system

\begin{tabular}{|c|c|c|c|c|c|c|c|c|}
\hline Item, ${ }^{1} \%$ & \multicolumn{4}{|c|}{ Treatment $^{2}$} & SEM & \multicolumn{3}{|c|}{ Contrast $P$-value ${ }^{3}$} \\
\hline Bacteroidetes & 45.2 & 46.7 & 45.5 & 46.4 & 1.38 & 0.51 & 0.68 & 0.64 \\
\hline Firmicutes & 31.9 & 29.3 & 29.2 & 29.1 & 1.12 & 0.02 & 0.94 & 0.94 \\
\hline Proteobacteria & 10.9 & 13.1 & 14.3 & 12.1 & 1.85 & 0.30 & 0.97 & 0.41 \\
\hline Cyanobacteria & 0.76 & 0.79 & 0.84 & 0.83 & 0.17 & 0.79 & 0.84 & 0.98 \\
\hline Tenericutes & 0.74 & 0.53 & 0.54 & 0.79 & 0.08 & 0.21 & 0.19 & 0.03 \\
\hline \multicolumn{9}{|l|}{ Particulate phase } \\
\hline Bacteroidetes & 40.1 & 39.7 & 39.5 & 38.7 & 1.32 & 0.59 & 0.70 & 0.68 \\
\hline Firmicutes & 40.2 & 38.9 & 38.2 & 40.2 & 1.27 & 0.47 & 0.87 & 0.26 \\
\hline Proteobacteria & 7.48 & 9.88 & 10.4 & 8.44 & 1.50 & 0.23 & 0.81 & 0.36 \\
\hline Spirochaetes & 5.56 & 5.24 & 5.75 & 5.56 & 0.43 & 0.93 & 0.43 & 0.75 \\
\hline
\end{tabular}

${ }^{1}$ Only phyla with relative abundance greater than $0.50 \%$ from $16 \mathrm{~S}$ rRNA sequencing were reported.

${ }^{2}$ Additives in the basal diet for each treatment (\% of diet DM): CTRL = control (no DFM added); MLP $=0.01 \%$ of a mix of Lactobacillus acidophilus and Propionibacterium freudenreichii $\mathrm{L} 1=0.05 \%$ Lactobacillus plantarum; $\mathrm{L} 2=0.10 \%$ L. plantarum.

${ }^{3}$ Significant differences were considered at $P \leq 0.05$, and a tendency between $P>0.05$ and $\leq 0.10$.

2010; Golder et al., 2018). Thus, these changes may have occurred through other mechanisms, such as other direct effects of L. plantarum on Tenericutes, through changes in the microbial community dynamics, or even by Tenericutes being part of the dynamic change caused by L1 treatment. Furthermore, most of the Tenericutes in this study were assigned to the family
Anaeroplasmataceae and genus Anaeroplasma, which followed the same effect of Tenericutes and reduced with L1 treatment (Supplemental Table S1; https:// doi.org/10.25338/B8P046). This bacterium has been described as having proteolytic properties (Joblin and Naylor, 2002), which could be a particular effect of $L$. plantarum on decreasing ruminal $\mathrm{NH}_{3}-\mathrm{N}$ concentration,

Table 4. Effects of direct-fed microbials (DFM) on the relative abundance of the most abundant bacterial families in a dual-flow continuous culture system

\begin{tabular}{|c|c|c|c|c|c|c|c|c|}
\hline \multirow[b]{2}{*}{ Item, ${ }^{1} \%$} & \multicolumn{4}{|c|}{ Treatment $^{2}$} & \multirow[b]{2}{*}{ SEM } & \multicolumn{3}{|c|}{ Contrast $P$-value ${ }^{3}$} \\
\hline & CTRL & MLP & L1 & L2 & & $\begin{array}{c}\text { CTRL vs. } \\
\text { DFM }\end{array}$ & $\begin{array}{l}\text { MLP vs. } \\
\text { L1 and L2 }\end{array}$ & L1 vs. L2 \\
\hline \multicolumn{9}{|l|}{ Fluid phase } \\
\hline Prevotellaceae & 35.2 & 36.8 & 36.3 & 36.7 & 1.23 & 0.37 & 0.86 & 0.83 \\
\hline Lachnospiraceae & 14.2 & 12.3 & 11.0 & 12.0 & 1.09 & 0.05 & 0.54 & 0.48 \\
\hline Succinivibrionaceae & 10.4 & 12.7 & 14.2 & 11.7 & 1.95 & 0.29 & 0.89 & 0.37 \\
\hline Ruminococcaceae & 4.80 & 4.26 & 3.96 & 4.59 & 0.34 & 0.19 & 0.97 & 0.20 \\
\hline Rikenellaceae & 3.49 & 3.48 & 3.30 & 3.83 & 0.40 & 0.91 & 0.87 & 0.36 \\
\hline \multicolumn{9}{|l|}{ Particulate phase } \\
\hline Prevotellaceae & 34.8 & 34.3 & 34.0 & 33.1 & 1.11 & 0.46 & 0.56 & 0.58 \\
\hline Lachnospiraceae & 22.8 & 22.3 & 21.4 & 23.1 & 0.93 & 0.58 & 0.97 & 0.21 \\
\hline Succinivibrionaceae & 7.06 & 9.58 & 10.2 & 8.07 & 1.54 & 0.22 & 0.82 & 0.33 \\
\hline Veillonellaceae & 9.34 & 8.73 & 8.97 & 9.02 & 0.64 & 0.54 & 0.73 & 0.96 \\
\hline
\end{tabular}

${ }^{1}$ Only the major bacterial families were reported.

${ }^{2}$ Additives in the basal diet for each treatment (\% of diet DM): CTRL = control (no DFM added); MLP =0.01\% of a mix of Lactobacillus acidophilus and Propionibacterium freudenreichii; $\mathrm{L} 1=0.05 \%$ Lactobacillus plantarum; $\mathrm{L} 2=0.10 \%$ L. plantarum.

${ }^{3}$ Significant differences were considered at $P \leq 0.05$, and a tendency between $P>0.05$ and $\leq 0.10$. 
as reported in our companion study (Monteiro et al., 2020). In the particulate phase, we observed a difference in the relative abundance of Actinobacteria, in which the $L$. plantarum treatments had greater relative abundance compared with the MLP treatment. Actinobacteria has been reported to be more abundant in the particulate phase in other studies because of its activity toward polysaccharide degradation (Deusch et al., 2017). These differences observed for Actinobacteria may be related to the fact that some bacteria from this phylum are lactic acid producers. and others are lactic acid utilizers (Golder et al., 2018), which may be in direct competition with the MLP treatment, as this contains both type of bacteria. These differences were not large enough to cause major changes in nutrient digestibility or SCFA concentration, as reported in our companion study (Monteiro et al., 2020); this led us to hypothesize that specific bacterial genera could instead be associated with improvements in $\mathrm{N}$ metabolism.

\section{Effects on Bacterial Community Genera}

To better understand changes in bacterial phyla and families, we conducted downstream analysis to the genus taxonomic level. A total of 168 genera were identified, and Prevotella_1 was the most abundant genus observed in both the fluid $(28.2 \%)$ and the particulate $(21.8 \%)$ phases. These findings are similar to previous findings reported by Dai et al. $(2017,2019)$ and Salfer et al. (2018) using the same system and by Henderson et al. (2015) across different ruminant species. From all the genera identified, the DFM inclusion decreased 6 genera and tended to decrease 8 others in the fluid phase, whereas 1 genus was decreased and 3 others tended to decrease in the particulate phase (Figure 2). All the bacteria that decreased with DFM inclusion in both phases were from the phylum Firmicutes and families Lachnospiraceae and Ruminococcaceae. The major effects of DFM inclusion seemed to be in the fluid phase, in which some of the most abundant ruminal bacteria were decreased (Butyrivibrio_2, Saccharofermentans, and Ruminococcus_1). All these 3 bacterial genera play an important role on the degradation of the plant cell wall (Deusch et al., 2017; Henderson et al., 2019; Palevich et al., 2019) and some proteins (Cotta and Hespell, 1986; Wallace, 1996) and thus are of great importance for the normal functioning of the microbial community of the rumen.

A genomic analysis of Butyrivibrio spp. (Palevich et al., 2019) reported a high activity of this genus toward the degradation of some components of plant cell walls and the fermentation of a variety of monosaccharides. Palevich et al. (2019) also demonstrated through sub- strate utilization tests that Butyrivibrio spp. are able to grow on pectin and hemicellulose, but not cellulose, and ferment most of the soluble carbohydrates present in the rumen. Similarly, Saccharofermentans spp. and Ruminococcus spp., despite having high cellulolytic activity, both ferment mono- and oligosaccharides as well (Chen et al., 2010; Deusch et al., 2017; La Reau and Suen, 2018). These 3 bacterial genera have been reported to generate butyric, acetic, lactic, formic, and fumaric acids, in their respective order of importance, as end products of fermentation (Chen et al., 2010; La Reau and Suen, 2018; Palevich et al., 2019). However, differences in nutrient digestibility or the concentration of most of these SCFA were not detected in our companion study (Monteiro et al., 2020).

Therefore, a plausible explanation for these major differences in bacterial genera was that the DFM tested in our study use soluble monosaccharides as substrates (Pedersen et al., 2012), making them likely associated with the fluid phase of the rumen. Because of that, we believe that the bacterial genera changes in the fluid phase were likely due to competition (Hibbing et al., 2010). Competition occurs when different bacteria utilize the same substrate in a shared environment (Hibbing et al., 2010). The DFM tested in our study and the bacterial genera that had their molar concentration decreased compete for the same monosaccharides, which may have enabled the tested DFM to use antimicrobial compounds (e.g., bacteriocins) against those bacteria (Riley and Wertz, 2002; Hibbing et al., 2010). Although the literature is scarce regarding studies evaluating the bacteriocin production by $L$. acidophilus NP51 and $L$. plantarum GB-LP1 that composed the DFM in our study, lactobacilli are known to be one of the major bacteriocin producers among other gram-positive bacteria (Suma et al., 1998; Maldonado et al., 2004; Perez et al., 2014). By contrast, the tested DFM possibly fermented those monosaccharides to lactic and acetic acid (Pedersen et al., 2012), the former of which was possibly later fermented by lactic acid-utilizing bacteria to propionic, acetic, or butyric acid (Chen et al., 2019), compensating the deficit caused by the negatively affected bacteria.

Interestingly, Butyrivibrio and Ruminococcus species have been reported to also have dipeptidyl peptidase activity in the rumen (Wallace, 1996), which would hydrolyze peptides into dipeptides for subsequent dipeptide hydrolysis to AA and deamination. By reducing the abundance of these bacteria, less dipeptides and free AA may have been released into fermentation and, therefore, less $\mathrm{NH}_{3}-\mathrm{N}$ produced. In fact, the inclusion of these DFM in our companion study decreased $\mathrm{NH}_{3}$ $\mathrm{N}$ concentration and daily outflow from fermentation 
(Monteiro et al., 2020). These findings suggest that monosaccharide fermentation may have been shifted toward DFM in our study, which decreased bacteria with the potential to hydrolyze peptides, consequently decreasing AA deamination and $\mathrm{NH}_{3}-\mathrm{N}$ production.

Similarly, the decrease in Lachnospiraceae_AC2044_ group and Lachnospiraceae_XPB1014_group in the fluid phase may also be associated with the decrease in $\mathrm{NH}_{3}-\mathrm{N}$ reported in our companion study. These genera have been reported to be negatively correlated with branched-chain volatile fatty acids in yaks grazing lowCP (10\%) and high-NDF shrubs (63\%; Yang et al., 2020). Although we did not observe branched-chain volatile fatty acid changes in our companion study

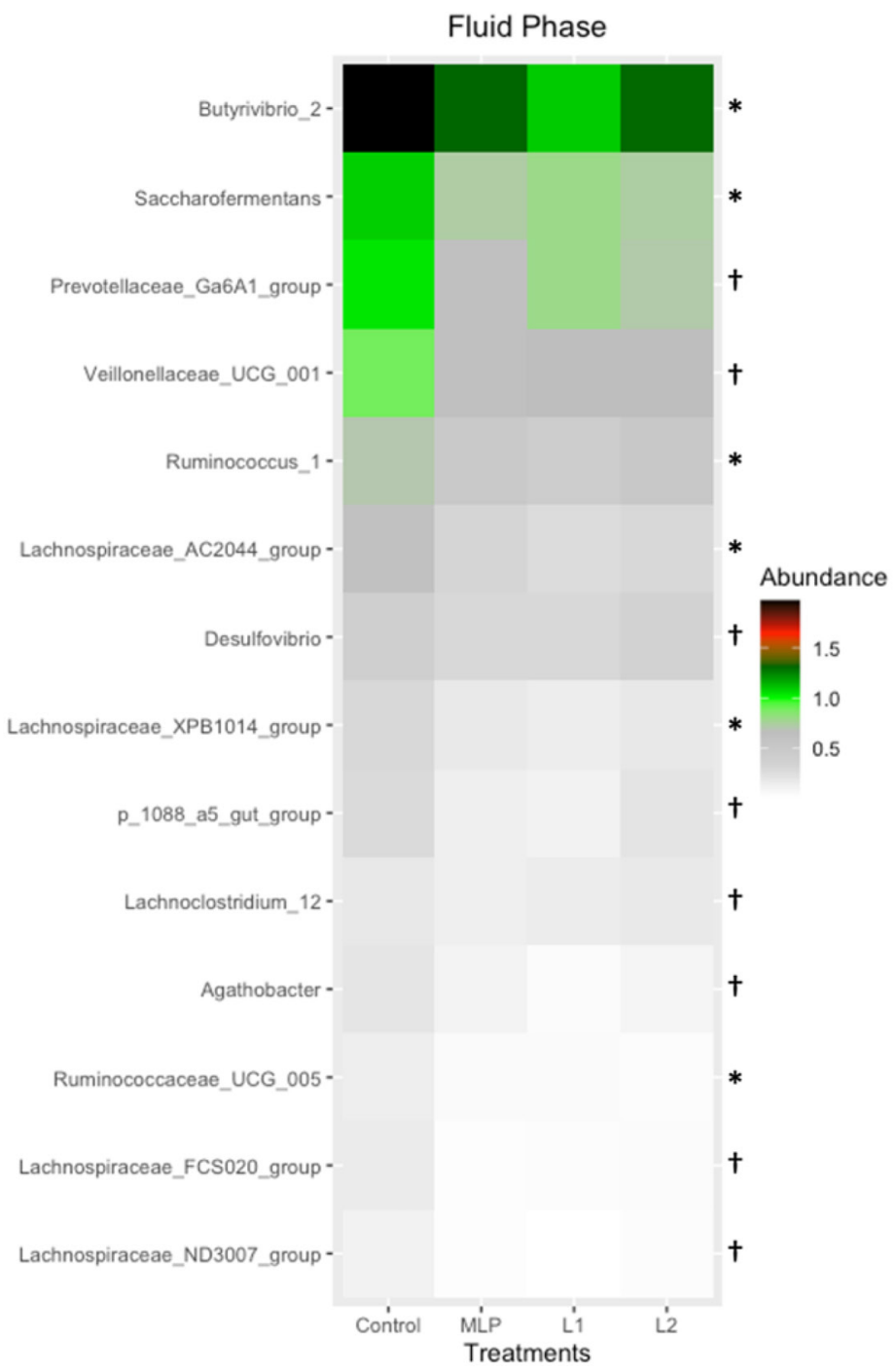

(Monteiro et al., 2020), these 2 genera may require branched-chain volatile fatty acids for branched-chain AA (BCAA) synthesis, as do other cellulolytic bacteria in the rumen that do not synthesize these SCFA by themselves (Allison and Bryant, 1963). The decrease of these bacteria may be associated with a decrease in BCAA deamination, which would directly decrease $\mathrm{NH}_{3}-\mathrm{N}$ production during fermentation. Finally, the main difference in the tendencies was in the decrease of the genera Prevotellaceae_Ga6A1_group due to DFM inclusion in both the fluid and particulate phases. This genus has been reported to be highly fibrolytic (Jami and Mizrahi, 2012; Guo et al., 2019), but as part of the Prevotellaceae family it may ferment a variety of

Figure 2. Relative abundance of all genera that decreased with the addition of direct-fed microbials (DFM) in both fluid and particulate phases. Additive inclusion in the basal diet for each treatment: CTRL $=$ control (no additives); $\mathrm{MLP}=0.01 \%$ of a mix of Lactobacillus acidophilus and Propionibacterium freudenreichii; L1 $=0.05 \%$ Lactobacillus plantarum; L2 $=0.10 \%$ L. plantarum. $*$ indicates significant contrast of control vs. DFM $(P<0.05) ; \dagger$ indicates a trend for the same contrast $(P>0.05$ and $\leq 0.10)$ 

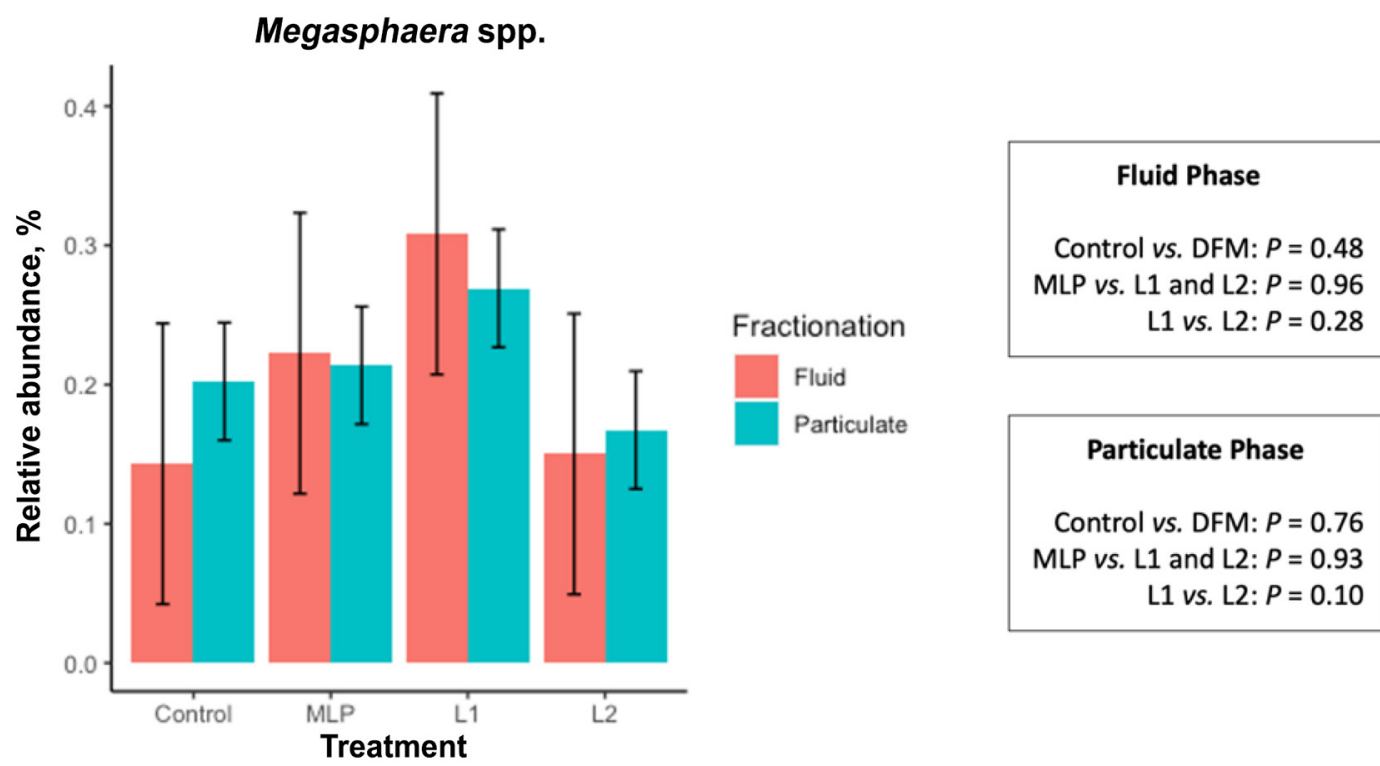

Figure 3. Relative abundance of Megasphaera spp. in both fluid and particulate phases when direct-fed microbials (DFM) were included in the basal diet. Additive inclusion in the basal diet for each treatment: CTRL = control (no additives); MLP $=0.01 \%$ of a mix of Lactobacillus acidophilus and Propionibacterium freudenreichii; $\mathrm{L} 1=0.05 \%$ Lactobacillus plantarum; L2 $=0.10 \%$ L. plantarum. Error bars indicate SE.

soluble carbohydrates, AA, and small peptides (Stevenson and Weimer, 2007), which is attributable to the same proposed mechanism explained earlier.

An effect of the type of DFM included was observed in the fluid phase for Lachnospiraceae_NK3A20_group $(P=0.04$; Supplemental Table S1), whereby L1 and L2 treatments reduced their relative abundance compared with MLP treatment. This genus has been reported to ferment sugars, proteins, and AA (Vacca et al., 2020), and their decrease due to L. plantarum may demonstrate the specificity of this bacterium when targeting other bacteria. We also observed an effect of L. plantarum level on the relative abundance of Prevotella_1 $(P=0.04)$, Prevotellaceae_YAB2003_group $(P=0.05)$, and Anaeroplasma $(P=0.03)$, whereby the first and the last increased with the greater inclusion level of $L$. plantarum but the second showed the opposite pattern. As described earlier, Prevotella is the most abundant genus in the rumen (Henderson et al., 2015) and can degrade a wide variety of substrates, such as carbohydrates and amino acids (Stevenson and Weimer, 2007). The greater inclusion level of L. plantarum, along with their greater negative effects on some fibrolytic bacteria, may have decreased competition to Prevotella that dominates fermentation; thus, this decrease in competition may have consequently been the factor increasing its population. In the particulate phase, fewer bacteria taxa were affected by DFM inclusion. Similar to the fluid phase, a greater inclusion level of L. plantarum increased the relative abundance of Lachnoclostridium_10
$(P=0.03)$, whereas Lachnospiraceae_AC2044_group $(P=0.05)$ and Ruminococcaceae_UCG_001 $(P=0.04)$ showed the opposite pattern. Lachnospiraceae and Ruminococcaceae are 2 major families of the phylum Firmicutes involved in cellulose and hemicellulose degradation (Wang et al., 2021), similar to those negatively affected in general by the DFM inclusion. In addition, the reason why the tested DFM in our study (especially L. plantarum) seemed to negatively affect specifically bacteria from the phylum Firmicutes and that are related to plant cell wall degradation is intriguing and warrants of further research.

We also analyzed the relative abundance of the Megasphaera population in the fluid and particulate phases to understand whether any of the tested DFM would increase its abundance through lactic acid stimulation. Megasphaera accounts for the metabolism of more than $80 \%$ of lactic acid in the rumen (Russell, 2002); thus, we expected that this population would be affected by DFM inclusion. We observed an effect of $L$. plantarum inclusion rate, whereby L1 had greater relative abundance of Megasphaera in the particulate phase compared with the L2 treatment (Figure 3). Although we did not observe lactic acid concentration differences across treatments in our companion study (Monteiro et al., 2020), the L1 treatment had numerically greater lactic acid concentration over time compared with the L2 treatment, which may have stimulated Megasphaera growth and propionic acid production (McAllister et al., 2011). The latter was confirmed in our companion 
study by a trend of increasing propionic acid concentration for the L1 treatment compared with the L2 treatment (Monteiro et al., 2020).

Interestingly, the relative abundances of Lactobacillus and Propionibacterium genera were not detected in our analysis. The samples used for the $16 \mathrm{~S}$ rRNA analyses were collected at $2,4,6$, and $8 \mathrm{~h}$ after feeding, which indicates a low survival rate of the tested DFM during fermentation and only an imminent effect immediately after introduction into the fermentor. The lack of sequences from these DFM in our analysis corroborates previous studies that evaluated the persistency of DFM in the rumen and concluded that the establishment of such populations is difficult, even when the DFM candidate was isolated from the rumen (Weimer et al., 2015). This suggests that dosing frequency is an issue that needs further investigation to ensure establishment and persistency of DFM in the rumen.
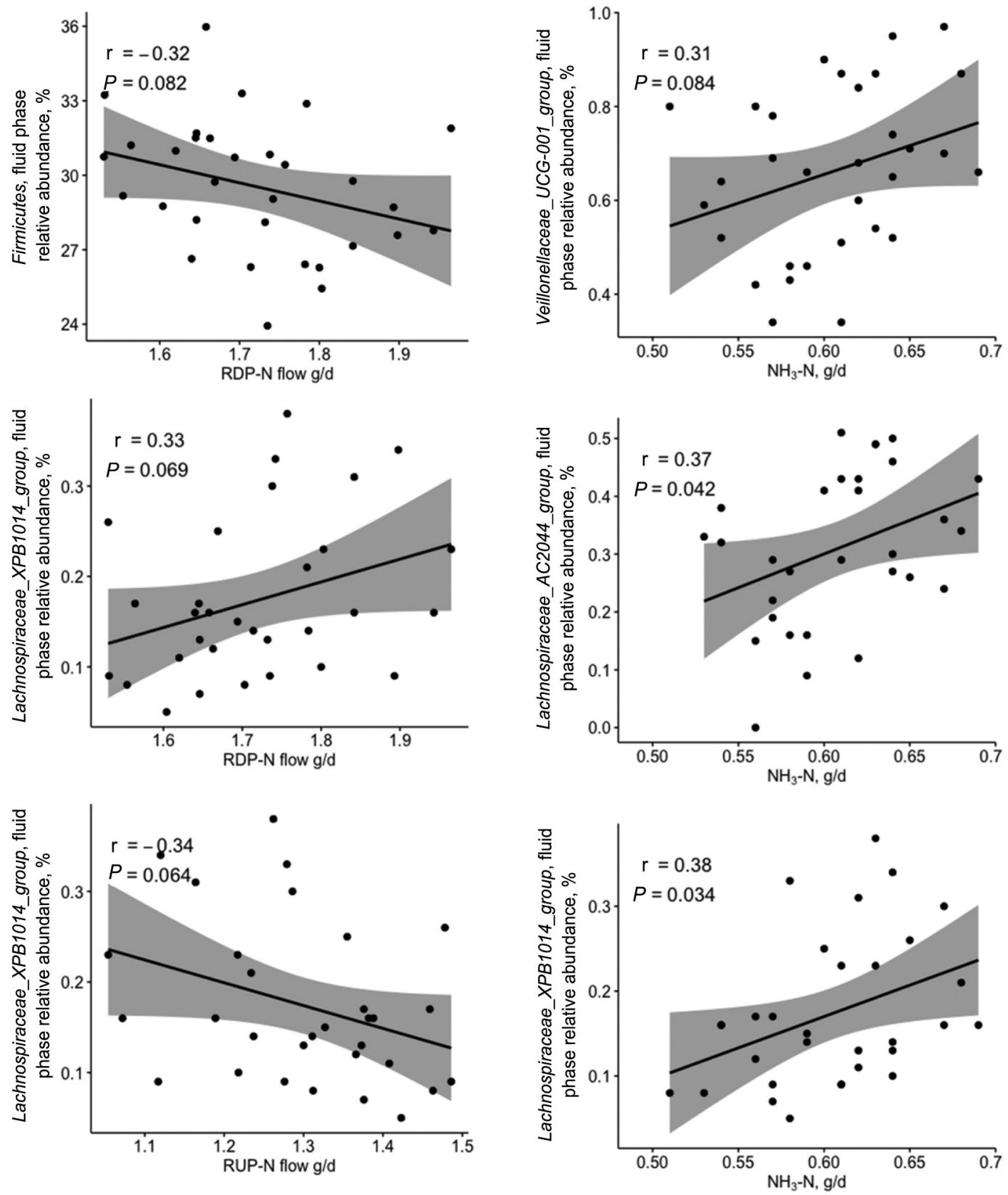

Figure 4. Pearson correlation analysis between the relative abundance of the main bacterial groups affected by inclusion of direct-fed microbials and the ruminal $\mathrm{N}$ metabolism variables observed in the study. Additive inclusion in the basal diet for each treatment: CTRL $=$ control (no additives); MLP $=0.01 \%$ of a mix of Lactobacillus acidophilus and Propionibacterium freudenreichii; L1 $=0.05 \%$ Lactobacillus plantarum; $\mathrm{L} 2=0.10 \%$ L. plantarum . 


\section{Correlations Between Bacterial Groups and Ruminal N Metabolism}

The correlation of the main bacterial groups affected by DFM inclusion and the ruminal $\mathrm{N}$ metabolism variables observed in this study are reported in Figure 4. Despite the effects of DFM on bacterial phyla, families, and some abundant genera in the fluid phase, only 2 genera (Lachnospiraceae_AC2044_group and Lachnospiraceae_XPB1014_group) in the fluid phase were positively correlated with $\mathrm{NH}_{3}-\mathrm{N}$ daily outflow from fermentation. However, Lachnospiraceae_XPB1014_group tended to be positively correlated with RDP-N flow and negatively correlated with RUP-N flow. Using the model we proposed earlier through the study of Yang et al. (2020) and these findings regarding their positive correlation with $\mathrm{NH}_{3}-\mathrm{N}$ daily outflow from fermentation, we are able to reinforce a possible direct effect of these bacteria on BCAA deamination and $\mathrm{NH}_{3}-\mathrm{N}$ production during fermentation.

Other possible correlations were observed among other bacterial groups, as with the phylum Firmicutes, which tended to be negatively correlated with RDP$\mathrm{N}$ flow (g/d), even though no changes in RDP-N flow were observed in our companion study (Monteiro et al., 2020). Other genera, such as Veillonellaceae_UCG-001, tended to be positively correlated with $\mathrm{NH}_{3}-\mathrm{N}$ flow, and Desulfovibrio tended to be negatively correlated with efficiency of $\mathrm{N}$ utilization $(P=0.07$ and $\mathrm{r}=-0.32$; data not shown). However, neither of these genera were affected by DFM inclusion in our study. It would have been informative to have data on the resilience of the DFM strains used in our study, to better understand their associations with specific changes in bacteria community and ruminal fermentation. In this study, the MLP treatment consisted of a binary culture of $L$. acidophilus NP51 and P. freudenreichii NP24. Thus, a pure culture of Lactobacillus, which would have been a good candidate to replace L. plantarum in the L1 and L2 treatments, was not available. Isolating the $L$. acidophilus NP51 strain from the mixed culture, and use of pure cultures of that strain for treatments L1 and L2, was not feasible in this study and therefore warrants further investigation.

\section{CONCLUSIONS}

Most of the changes in the ruminal microbiome due to DFM inclusion occurred in the fluid phase of the fermentation. Despite minor changes in some specific genera, competition was possibly one of the major mechanisms that could explain the microbiome changes in this study. Two major groups of bacteria were decreased by DFM inclusion: those directly associated with $\mathrm{NH}_{3}-\mathrm{N}$ production through a possible BCAA deamination, and those indirectly associated with $\mathrm{NH}_{3}-\mathrm{N}$ production via dipeptidase activity during fermentation. Except for a slight increase in Megasphaera elsdenii in the lower inclusion rate of $L$. plantarum compared with the higher inclusion rate, little to no differences were observed between the DFM treatments tested on the ruminal microbial community composition. Therefore, the effects of the tested DFM on ruminal fermentation were probably caused not by the decrease of a single bacterial group but by the decrease of different bacteria that together resulted in the observed effects here and in our companion study.

\section{ACKNOWLEDGMENTS}

The authors acknowledge all the help received from visiting scholars, interns, and masters and $\mathrm{PhD}$ students during the experiments. The authors are also grateful for funding for the experiments from the Institute of Food and Agricultural Sciences of the University of Florida (Gainesville). The authors have not stated any conflicts of interest.

\section{REFERENCES}

Allison, M. J., and M. P. Bryant. 1963. Biosynthesis of branched-chain amino acids from branched-chain fatty acids by rumen bacteria. Arch. Biochem. Biophys. 101:269-277. https://doi.org/10.1016/ S0003-9861(63)80012-0.

Bach, A., and M. D. Stern. 1999. Effects of different levels of methionine and ruminally undegradable protein on the amino acid profile of effluent from continuous culture fermenters. J. Anim. Sci. 77:3377-3384. https://doi.org/10.2527/1999.77123377x.

Boyd, J., J. W. West, and J. K. Bernard. 2011. Effects of the addition of direct-fed microbials and glycerol to the diet of lactating dairy cows on milk yield and apparent efficiency of yield. J. Dairy Sci. 94:4616-4622. https://doi.org/10.3168/jds.2010-3984.

Brandao, V. L. N., L. G. Silva, E. M. Paula, H. F. Monteiro, X. Dai, A. L. J. Lelis, A. Faccenda, S. R. Poulson, and A. P. Faciola. 2018. Effects of replacing canola meal with solvent-extracted camelina meal on microbial fermentation in a dual-flow continuous culture system. J. Dairy Sci. 101:9028-9040. https://doi.org/10.3168/jds .2018-14826.

Bryant, M. P., and N. Small. 1956. The anaerobic monotrichous butyric acid-producing curved rod-shaped bacteria of the rumen. J. Bacteriol. 72:16-21. https://doi.org/10.1128/jb.72.1.16-21.1956.

Callahan, B. J., P. J. McMurdie, M. J. Rosen, A. W. Han, A. J. A. Johnson, and S. P. Holmes. 2016. DADA2: High-resolution sample inference from Illumina amplicon data. Nat. Methods 13:581-583. https://doi.org/10.1038/nmeth.3869.

Calsamiglia, S., M. D. Stern, and J. L. Firkins. 1996. Comparison of nitrogen-15 and purines as microbial markers in continuous culture. J. Anim. Sci. 74:1375-1381. https://doi.org/10.2527/1996 $.7461375 x$

Chen, L., Y. Shen, C. Wang, L. Ding, F. Zhao, M. Wang, J. Fu, and H. Wang. 2019. Megasphaera elsdenii lactate degradation pattern shifts in rumen acidosis models. Front. Microbiol. 10:162. https:// doi.org/10.3389/fmicb.2019.00162.

Chen, S., L. Niu, and Y. Zhang. 2010. Saccharofermentans acetigenes gen. nov., sp. nov., an anaerobic bacterium isolated from sludge treating brewery wastewater. Int. J. Syst. Evol. Microbiol. 60:2735-2738. https://doi.org/10.1099/ijs.0.017590-0. 
Contreras-Govea, F. E., R. E. Muck, G. A. Broderick, and P. J. Weimer. 2013. Lactobacillus plantarum effects on silage fermentation and in vitro microbial yield. Anim. Feed Sci. Technol. 179:6168. https://doi.org/10.1016/j.anifeedsci.2012.11.008.

Contreras-Govea, F. E., R. E. Muck, D. R. Mertens, and P. J. Weimer. 2011. Microbial inoculant effects on silage and in vitro ruminal fermentation, and microbial biomass estimation for alfalfa, bmr corn, and corn silages. Anim. Feed Sci. Technol. 163:2-10. https:/ /doi.org/10.1016/j.anifeedsci.2010.09.015.

Cook, A. R., P. W. Riley, H. Murdoch, P. N. Evans, and I. R. McDonald. 2007. Howardella ureilytica gen. nov., sp. nov., a Grampositive, coccoid-shaped bacterium from a sheep rumen. Int. J. Syst. Evol. Microbiol. 57:2940-2945. https://doi.org/10.1099/ijs.0 .64819-0.

Cotta, M. A., and R. B. Hespell. 1986. Proteolytic activity of the ruminal bacterium Butyrivibrio fibrisolvens. Appl. Environ. Microbiol. 52:51-58. https://doi.org/10.1128/aem.52.1.51-58.1986.

Czerkawski, J. W. 1986. Degradation of solid feeds in the rumen: Spatial distribution of microbial activity and its consequences. Proc. 6th International Symposium on Ruminant Physiology, Banff, Alberta, Canada.

Dai, X., E. M. Paula, A. L. J. Lelis, L. G. Silva, V. L. N. Brandao, H. F. Monteiro, P. Fan, S. R. Poulson, K. C. Jeong, and A. P. Faciola. 2019. Effects of lipopolysaccharide dosing on bacterial community composition and fermentation in a dual-flow continuous culture system. J. Dairy Sci. 102:334-350. https://doi.org/10.3168/jds .2018-14807.

Dai, X., P. J. Weimer, K. A. Dill-McFarland, V. L. N. Brandao, G. Suen, and A. P. Faciola. 2017. Camelina seed supplementation at two dietary fat levels change ruminal bacterial community composition in a dual-flow continuous culture system. Front. Microbiol. 8:2147. https://doi.org/10.3389/fmicb.2017.02147.

de Assis Lage, C. F., S. E. Räisänen, A. Melgar, K. Nedelkov, X. Chen, J. Oh, M. E. Fetter, N. Indugu, J. S. Bender, B. Vecchiarelli, M. L. Hennessy, D. Pitta, and A. N. Hristov. 2020. Comparison of two sampling techniques for evaluating ruminal fermentation and microbiota in the planktonic phase of rumen digesta in dairy cows. Front. Microbiol. 11:618032. https://doi.org/10.3389/fmicb.2020 .618032 .

Dehority, B. A. 1969. Pectin-fermenting bacteria isolated from the bovine rumen. J. Bacteriol. 99:189-196. https://doi.org/10.1128/ jb.99.1.189-196.1969.

Del Bianco Benedeti, P., L. Galoro da Silva, E. Marostegan de Paula, T. Shenkoru, M. I. Marcondes, H. F. Monteiro, B. Amorati, Y. Yeh, S. R. Poulson, and A. P. Faciola. 2015. Effects of partial replacement of corn with glycerin on ruminal fermentation in a dualflow continuous culture system. PLoS One 10:e0143201. https:// doi.org/10.1371/journal.pone.0143201.

Deusch, S., A. Camarinha-Silva, J. Conrad, U. Beifuss, M. Rodehutscord, and J. Seifert. 2017. A structural and functional elucidation of the rumen microbiome influenced by various diets and microenvironments. Front. Microbiol. 8:1605. https://doi.org/10 $.3389 /$ fmicb.2017.01605.

Golder, H. M., J. M. Thomson, S. E. Denman, C. S. McSweeney, and I. J. Lean. 2018. Genetic markers are associated with the ruminal microbiome and metabolome in grain and sugar challenged dairy heifers. Front. Genet. 9:62. https://doi.org/10.3389/fgene.2018 .00062

Guo, B., D. Li, B. Zhou, Y. Jiang, H. Bai, Y. Zhang, Q. Xu, W. Zhao, and G. Chen. 2019. Comparative characterization of bacterial communities in geese consuming of different proportions of ryegrass. PLoS One 14:e0223445. https://doi.org/10.1371/journal .pone. 0223445 .

Henderson, G., F. Cox, S. Ganesh, A. Jonker, W. YoungGlobal Rumen Census Collaborators, and P. H. Janssen. 2015. Rumen microbial community composition varies with diet and host, but a core microbiome is found across a wide geographical range. Sci. Rep. 5:14567. https://doi.org/10.1038/srep14567.

Henderson, G., F. Cox, S. Kittelmann, V. H. Miri, M. Zethof, S. J. Noel, G. C. Waghorn, and P. H. Janssen. 2013. Effect of DNA extraction methods and sampling techniques on the apparent struc- ture of cow and sheep rumen microbial communities. PLoS One 8:e74787. https://doi.org/10.1371/journal.pone.0074787.

Henderson, G., P. Yilmaz, S. Kumar, R. J. Forster, W. J. Kelly, S. C. Leahy, L. L. Guan, and P. H. Janssen. 2019. Improved taxonomic assignment of rumen bacterial $16 \mathrm{~S}$ rRNA sequences using a revised SILVA taxonomic framework. PeerJ 7:e6496. https://doi .org/10.7717/peerj.6496.

Hibbing, M. E., C. Fuqua, M. R. Parsek, and S. B. Peterson. 2010. Bacterial competition: Surviving and thriving in the microbial jungle. Nat. Rev. Microbiol. 8:15-25. https://doi.org/10.1038/ nrmicro2259.

Hoover, W. H., B. A. Crooker, and C. J. Sniffen. 1976. Effects of differential solid-liquid removal rates on protozoa numbers in continuous cultures of rumen contents. J. Anim. Sci. 43:528-534. https:// doi.org/10.2527/jas1976.432528x

Jami, E., and I. Mizrahi. 2012. Composition and similarity of bovine rumen microbiota across individual animals. PLoS One 7:e33306. https://doi.org/10.1371/journal.pone.0033306.

Joblin, K. N., and G. E. Naylor. 2002. The ruminal mycoplasmas: A review. J. Appl. Anim. Res. 21:161-179. https://doi.org/10.1080/ 09712119.2002.9706368.

Kozich, J. J., S. L. Westcott, N. T. Baxter, S. K. Highlander, and P. D. Schloss. 2013. Development of a dual-index sequencing strategy and curation pipeline for analyzing amplicon sequence data on the MiSeq Illumina sequencing platform. Appl. Environ. Microbiol. 79:5112-5120. https://doi.org/10.1128/AEM.01043-13.

Krieg, N. R., J. T. Staley, D. R. Brown, B. P. Hedlund, B. J. Paster, N. L. Ward, W. Ludwig, and W. B. Whitman. 2010. Bergey's Manual of Systematic Bacteriology. Springer New York.

Kung, L., M. R. Stokes, and C. J. Lin. 2003. Chapter 7: Silage additives. In Silage Science and Technology, Vol. 42. D. R. Buxton, R. E. Muck, and J. H. Harrison, ed. American Society of Agronomy, Crop Science Society of America, Soil Science Society of America.

La Reau, A. J., and G. Suen. 2018. The ruminococci: Key symbionts of the gut ecosystem. J. Microbiol. 56:199-208. https://doi.org/10 $.1007 / \mathrm{s} 12275-018-8024-4$.

Lahti, L., and S. Shetty. 2017. Microbiome R Package: Tools for Microbiome Analysis in R. Bioconductor, www.bioconductor.org.

Maldonado, A., R. Jiménez-Díaz, and J. L. Ruiz-Barba. 2004. Induction of plantaricin production in Lactobacillus plantarum NC8 after coculture with specific gram-positive bacteria is mediated by an autoinduction mechanism. J. Bacteriol. 186:1556-1564. https:/ /doi.org/10.1128/JB.186.5.1556-1564.2004.

McAllister, T. A., K. A. Beauchemin, A. Y. Alazzeh, J. Baah, R. M. Teather, and K. Stanford. 2011. Review: The use of direct fed microbials to mitigate pathogens and enhance production in cattle. Can. J. Anim. Sci. 91:193-211. https://doi.org/10.4141/cjas10047.

McMurdie, P. J., and S. Holmes. 2013. Phyloseq: An R package for reproducible interactive analysis and graphics of microbiome census data. PLoS One 8:e61217. https://doi.org/10.1371/journal.pone .0061217 .

Monteiro, H. F., A. L. J. Lelis, V. L. N. Brandao, A. Faccenda, A. S. Avila, J. Arce-Cordero, L. G. Silva, X. Dai, R. Restelatto, P. Carvalho, L. R. Lima, and A. P. Faciola. 2020. In vitro evaluation of Lactobacillus plantarum as direct-fed microbials in high-producing dairy cows diets. Transl. Anim. Sci. 4:214-228. https://doi.org/10 $.1093 / \mathrm{tas} / \mathrm{txz} 187$

Monteiro, H. F., E. M. Paula, R. E. Muck, G. A. Broderick, and A. P. Faciola. 2021. Effects of lactic acid bacteria in a silage inoculant on ruminal nutrient digestibility, nitrogen metabolism, and lactation performance of high-producing dairy cows. J. Dairy Sci. 104:8826-8834. https://doi.org/10.3168/jds.2021-20155.

Muck, R. 2013. Recent advances in silage microbiology. Agric. Food Sci. 22:3-15. https://doi.org/10.23986/afsci.6718.

Muck, R. E., E. M. G. Nadeau, T. A. McAllister, F. E. ContrerasGovea, M. C. Santos, and L. Kung Jr.. 2018. Silage review: Recent advances and future uses of silage additives. J. Dairy Sci. 101:3980-4000. https://doi.org/10.3168/jds.2017-13839.

National Research Council. 2001. Nutrient Requirements of Dairy Cattle. 7th rev. ed. Natl. Acad. Press. 
Oksanen, J., G. Blanchet, M. Friendly, R. Kindt, P. Legendre, D. McGlinn, P. R. Minchin, R. B. O'Hara, G. L. Simpson, P. Solymos, M. Henry, H. Stevens, E. Szoecs, and H. Wagner. 2020. Vegan: Community ecology package. $\mathrm{R}$ package version 2.5-7.

Oliveira, A. S., Z. G. Weinberg, I. M. Ogunade, A. A. P. Cervantes, K. G. Arriola, Y. Jiang, D. Kim, X. Li, M. C. M. Gonçalves, D. Vyas, and A. T. Adesogan. 2017. Meta-analysis of effects of inoculation with homofermentative and facultative heterofermentative lactic acid bacteria on silage fermentation, aerobic stability, and the performance of dairy cows. J. Dairy Sci. 100:4587-4603. https://doi .org $/ 10.3168 /$ jds.2016-11815.

Palevich, N., W.J. Kelly, S.C. Leahy, S. Denman, E. Altermann, J. Rakonjac, and G.T. Attwood. 2019. Comparative genomics of rumen Butyrivibrio spp. uncovers a continuum of polysaccharide-degrading capabilities. Appl. Environ. Microbiol. 86:e01993-19. https:// doi.org/10.1128/AEM.01993-19.

Paula, E. M., H. F. Monteiro, L. G. Silva, P. D. B. Benedeti, J. L. P. Daniel, T. Shenkoru, G. A. Broderick, and A. P. Faciola. 2017. Effects of replacing soybean meal with canola meal differing in rumen-undegradable protein content on ruminal fermentation and gas production kinetics using 2 in vitro systems. J. Dairy Sci. 100:5281-5292. https://doi.org/10.3168/jds.2016-12301.

Pedersen, M. B., P. Gaudu, D. Lechardeur, M.-A. Petit, and A. Gruss. 2012. Aerobic respiration metabolism in lactic acid bacteria and uses in biotechnology. Annu. Rev. Food Sci. Technol. 3:37-58. https://doi.org/10.1146/annurev-food-022811-101255.

Perez, R. H., T. Zendo, and K. Sonomoto. 2014. Novel bacteriocins from lactic acid bacteria (LAB): Various structures and applications. Microb. Cell Fact. 13(Suppl. 1):S3. https://doi.org/10.1186/ 1475-2859-13-S1-S3.

Philippeau, C., A. Lettat, C. Martin, M. Silberberg, D. P. Morgavi, A. Ferlay, C. Berger, and P. Nozière. 2017. Effects of bacterial directfed microbials on ruminal characteristics, methane emission, and milk fatty acid composition in cows fed high- or low-starch diets. J. Dairy Sci. 100:2637-2650. https://doi.org/10.3168/jds.2016-11663.

Plaizier, J. C., D. O. Krause, G. N. Gozho, and B. W. McBride. 2008. Subacute ruminal acidosis in dairy cows: The physiological causes, incidence and consequences. Vet. J. 176:21-31. https://doi.org/10 .1016/j.tvj1.2007.12.016.

Pruesse, E., C. Quast, K. Knittel, B. M. Fuchs, W. Ludwig, J. Peplies, and F. O. Glockner. 2007. SILVA: A comprehensive online resource for quality checked and aligned ribosomal RNA sequence data compatible with ARB. Nucleic Acids Res. 35:7188-7196. https:// doi.org/10.1093/nar/gkm864.

Raeth-Knight, M. L., J. G. Linn, and H. G. Jung. 2007. Effect of direct-fed microbials on performance, diet digestibility, and rumen characteristics of Holstein dairy cows. J. Dairy Sci. 90:1802-1809. https://doi.org/10.3168/jds.2006-643.

Riley, M. A., and J. E. Wertz. 2002. Bacteriocins: Evolution, ecology, and application. Annu. Rev. Microbiol. 56:117-137. https://doi .org/10.1146/annurev.micro.56.012302.161024.

Roesch, L. F. W., P. T. Dobbler, V. S. Pylro, B. Kolaczkowski, J. C. Drew, and E. W. Triplett. 2020. PIME: A package for discovery of novel differences among microbial communities. Mol. Ecol. Resour. 20:415-428. https://doi.org/10.1111/1755-0998.13116.

Rosen, M. J., B. J. Callahan, D. S. Fisher, and S. P. Holmes. 2012. Denoising PCR-amplified metagenome data. BMC Bioinformatics 13:283. https://doi.org/10.1186/1471-2105-13-283.

Russell, J. B. 2002. Rumen Microbiology and Its Role in Ruminant Nutrition. ARS-USDA, Ithaca, NY.

Salfer, I. J., C. Staley, H. E. Johnson, M. J. Sadowsky, and M. D. Stern. 2018. Comparisons of bacterial and archaeal communities in the rumen and a dual-flow continuous culture fermentation system using amplicon sequencing. J. Anim. Sci. 96:1059-1072. https:// doi.org/10.1093/jas/skx056.

Silva, L. G., J. Bunkers, E. M. Paula, T. Shenkoru, Y. Yeh, B. Amorati, D. Holcombe, and A. P. Faciola. 2016. Effects of flaxseed and chia seed on ruminal fermentation, nutrient digestibility, and longchain fatty acid flow in a dual-flow continuous culture system. J. Anim. Sci. 94:1600-1609. https://doi.org/10.2527/jas.2015-9750.

Stackebrandt, E. 2014. The family Lachnospiraceae. Pages 197-201 in The Prokaryotes: Firmicutes and Tenericutes. E. Rosenberg, E. F. DeLong, S. Lory, E. Stackebrandt, and F. Thompson, ed. Springer Berlin Heidelberg.

Stevenson, D. M., and P. J. Weimer. 2007. Dominance of Prevotella and low abundance of classical ruminal bacterial species in the bovine rumen revealed by relative quantification real-time PCR. Appl. Microbiol. Biotechnol. 75:165-174. https://doi.org/10.1007/ s00253-006-0802-y.

Suma, K., M. C. Misra, and M. C. Varadaraj. 1998. Plantaricin LP84, a broad-spectrum heat-stable bacteriocin of Lactobacillus plantarum NCIM 2084 produced in a simple glucose broth medium. Int. J. Food Microbiol. 40:17-25. https://doi.org/10.1016/S0168 $-1605(98) 00010-5$

Vacca, M., G. Celano, F. M. Calabrese, P. Portincasa, M. Gobbetti, and M. De Angelis. 2020. The controversial role of human gut Lachnospiraceae. Microorganisms 8:573. https://doi.org/10.3390/ microorganisms 8040573.

Wallace, R. J. 1996. Ruminal microbial metabolism of peptides and amino acids. J. Nutr. 126(Suppl. 4):1326S-1334S. https://doi.org/ 10.1093/jn/126.suppl_4.1326S.

Wallace, R. J., and M. L. Brammall. 1985. The role of different species of bacteria in the hydrolysis of protein in the rumen. Microbiology (Reading) 131:821-832. https://doi.org/10.1099/00221287-131-4 $-821$.

Wang, Y., X. Nan, Y. Zhao, Y. Wang, L. Jiang, and B. Xiong. 2021. Ruminal degradation of rumen-protected glucose influences the ruminal microbiota and metabolites in early-lactation dairy cows. Appl. Environ. Microbiol. 87:e01908-e01920. https://doi.org/10 .1128/AEM.01908-20.

Weimer, P. J., L. Da Silva Cabral, and F. Cacite. 2015. Effects of ruminal dosing of Holstein cows with Megasphaera elsdenii on milk fat production, ruminal chemistry, and bacterial strain persistence. J. Dairy Sci. 98:8078-8092. https://doi.org/10.3168/jds.2015-9721.

Weinberg, Z. G., Y. Chen, and M. Gamburg. 2004a. The passage of lactic acid bacteria from silage into rumen fluid in vitro studies. J. Dairy Sci. 87:3386-3397. https://doi.org/10.3168/jds.S0022 -0302(04)73474-8.

Weinberg, Z. G., R. E. Muck, and P. J. Weimer. 2003. The survival of silage inoculant lactic acid bacteria in rumen fluid. J. Appl. Microbiol. 94:1066-1071. https://doi.org/10.1046/j.1365-2672.2003 .01942.x.

Weinberg, Z.G., R.E. Muck, P.J. Weimer, Y. Chen, and M. Gamburg. 2004b. Lactic acid bacteria used in inoculants for silage as probiotics for ruminants. ABAB 118:1-9. https://doi.org/10.1385/ABAB: 118:1-3:001.

Whittaker, R. H. 1972. Evolution and measurement of species diversity. Taxon 21:213-251. https://doi.org/10.2307/1218190.

Wickham, H. 2016. Ggplot2: Elegant Graphics for Data Analysis. 2nd ed. Springer. https://doi.org/10.1007/978-0-387-98141-3.

Yang, C., G. Tsedan, Y. Liu, and F. Hou. 2020. Shrub coverage alters the rumen bacterial community of yaks (Bos grunniens) grazing in alpine meadows. J. Anim. Sci. Technol. 62:504-520. https://doi .org/10.5187/jast.2020.62.4.504. 